УДК 331.556.46(=163.3/.6)(100)“196/198“

94:314.151.3-054.73(=163.3/.6)(100)“196/198“

Petar DRAGIŠIĆ, Ph. D.

\title{
SEARCHING FOR EL DORADO. WORKERS FROM SERBIA TEMPORARY EMPLOYED ABROAD FROM THE 1960S TO THE DISSOLUTION OF YUGOSLAVIA*
}

\begin{abstract}
The paper examines labor emigration from Serbia from the beginning of large-scale emigration in the 1960s to the breakup of the Socialist Federal Republic of Yugoslavia in the early 1990s. The research focuses, among others, on push factors of the Gastarbeiter emigration from Serbia/Yugoslavia in the 1960s and 1970s, the emigration policy of the communist regime in Yugoslavia and the financial impact of the labor emigration on the Serbian economy. The research is based on archival data analysis, statistical reports and secondary sources.
\end{abstract}

Key words: labor emigration, Gastarbeiter, Serbia, Yugoslavia, remittances

The political tensions as well as the economic stagnation in Yugoslavia in the 1960s brought to light the fragility of the 'Yugoslav experiment'. The dream of the socialist paradise was replaced by the pessimistic predictions of the Yugoslav future. The rise of nationalism demonstrated the unsustainability of the Yugoslav motto - brotherhood and unity (Bratstvo i jedinstvo). The precarious political situation was accompanied by economic problems. The failure of the economic reform (in the mid-1960s) generated the intense pressure on the Yugoslav labor market. In 1976, the unemployment rate in the most underdeveloped regions of Yugoslavia (Socialist Autonomous Province of Kosovo and Socialist Republic of Macedonia) exceeded twenty per cent (20\%). The unemployment rate in central Serbia and Montenegro was considerably high as well. ${ }^{1}$ This push factor, coupled with an acute need of the booming Western economies for additional labor force triggered the biggest emigration wave in the history of socialist Yugoslavia.

This article has been written within the framework of the scholarly project Tradition and Transformation - Historical Heritage and National Identity in Serbia in 20 th Century (№ 47019), financed by the Ministry of Education, Science and Technological Development Republic of Serbia.

1 Arhiv Jugoslavije (AJ), Socijalistički savez radnog naroda Jugoslavije (142), f-740, Savezni komitet za rad i zapošljavanje, Izveštaj o ostvarivanju politike zapošljavanja, zapošljavanja u inostranstvu, i postepenog vraćanja jugoslovenskih građana sa privremenog rada u inostranstvu u 1977. godini (analitičko-dokumentarna osnova), March 1978. The average unemployment rate in Yugoslavia in 1976 accounted for $11.4 \%$. 
The massive migration from Yugoslavia started in the mid-1960s reaching its peak at the beginning of the $1970 \mathrm{~s}^{2}$ According to Yugoslav statistics, only in 1970 about 225,000 Yugoslav migrant workers were employed abroad. By the beginning of the 1970s the number of Yugoslav labor migrants exceeded one million. Nevertheless, the process decelerated in the first half of the 1970s due to the immigration restrictions imposed in the main receiving countries in Western Europe, following the oil crisis. Whereas in 1973 more than 100,000 Yugoslavs found employment abroad, in the following year only 20,000 job seekers from Yugoslavia joined the colony of Yugoslav Gastarbeiter. ${ }^{3}$

Yugoslav migrant workers 1964-19774

\begin{tabular}{|r|r|r|}
\hline & $\begin{array}{c}\text { Annual number of Yugoslav } \\
\text { labor migrants employed abroad }\end{array}$ & $\begin{array}{c}\text { Total number of Yugoslav } \\
\text { labor migrants }\end{array}$ \\
\hline 1964 & 20,000 & 138,000 \\
\hline 1965 & 41,000 & 174,000 \\
\hline 1966 & 110,000 & 275,000 \\
\hline 1967 & 40,000 & 296,000 \\
\hline 1968 & 124,000 & 401,000 \\
\hline 1969 & 187,000 & 572,000 \\
\hline 1970 & 225,000 & 783,000 \\
\hline 1971 & 151,000 & 923,000 \\
\hline 1972 & 108,000 & $1,020,000$ \\
\hline 1973 & 103,000 & $1,100,000$ \\
\hline 1974 & 20,000 & $1,035,000$ \\
\hline 1975 & 24,000 & 940,000 \\
\hline 1976 & 27,000 & 870,000 \\
\hline 1977 & 25,000 & 825,000 \\
\hline
\end{tabular}

2 On labor migrations from socialist Yugoslavia, see, among others: Vladimir Ivanović, Geburtstag pišeš normalno. Jugoslovenski gastarbajteri u SR Nemačkoj i Austriji: 1965-1973, Beograd, 2012; Ivana Dobrivojević, „U potrazi za blagostanjem. Odlazak jugoslovenskih radnika na rad u zemlje Zapadne Evrope 1960-1976“, Istorija 20. veka, 1 (2008), 89-100; Slobodan Selinić, „Ekonomska emigracija iz Jugoslavije šezdesetih godina XX veka“, in 1968 - četrdeset godina posle, ed. Radmila Radić, Beograd, 2008, 549-573; Vladimir Ivanović, „Brantova istočna politika i jugoslovenska ekonomska emigracija u SR Nemačkoj“, in 1968 - četrdeset godina posle, ed. Radmila Radić, Beograd, 2008, 275-292; Milena Primorac, Strani radnici. Sociološki aspekti privremene ekonomske emigracije, Beograd, 1980; Ivo Baučić, Social Aspects of External Migration of Workers and the Yugoslav Experience in the Social Protection of Migrants, Zagreb, 197; Othmar Nikola Haberl, Die Abwanderung von Arbeitskräften aus Jugoslawien, München, 1978; Ulf Brunnbauer, ,Jugoslawische Geschichte als Migrationsgeschichte (19. und 20. Jahrhundert)“ in Schnittstellen. Gesellschaft, Nation, Konflikt und Erinnerung in Südosteuropa. Festschrift für Holm Sundhaussen zum 65. Geburtstag, ed. Ulf Brunnbauer et al., München, 2007, 111132; Ulf Brunnbauer, „Emigration aus Südosteuropa, 19.-21. Jahrhundert. Kontinuitäten, Brüche, Perspektiven" in Südosteuropa. Traditionen als Macht, ed. Emil Brix et al., Wien/München, Verlag für Geschichte und Politik/Oldenbourg Wissenschaftsverlag 2007, 119-142. 
The substantial majority of the Yugoslav jobseekers (cc. 75\%) settled in West European receiving countries. The majority of the Yugoslav Gastarbeiter immigrated to the German speaking countries. According to Yugoslav statistics, there were 535,000 Yugoslav Gastarbeiter living in the Federal Republic of Germany (Bundesrepublik Deutschland) in 1973. In the same year the Yugoslav communities in Austria and Switzerland numbered 195,000 and 35,000 labor migrants respectively. Moreover, a considerable number of Yugoslav migrant workers resided in France (75,000 in 1973). ${ }^{5}$

By 1970 the Yugoslav regime signed bilateral agreements on recruitment of Yugoslav workers with the most important receiving countries: France (in 1965), Austria and Sweden (in 1966), the Federal Republic of Germany (in 1968) as well as with Belgium, Luxemburg, Netherlands and Australia (in 1970). ${ }^{6}$

Yugoslav migrant workers 1973/1977 by countries of residence ${ }^{7}$

\begin{tabular}{|c|r|r|r|r|}
\hline & 1973 (in 1000) & $1973(\%)$ & 1977 (in 1000) & 1977 (\%) \\
\hline FR Germany & 535 & 48.6 & 350 & 42.3 \\
\hline Austria & 195 & 17.7 & 120 & 14.6 \\
\hline France & 75 & 6.8 & 58 & 7 \\
\hline Switzerland & 35 & 3.2 & 25 & 3 \\
\hline Sweden & 25 & 2.3 & 25 & 3 \\
\hline Netherlands & 12 & 1.1 & 8 & 1 \\
\hline Belgium & 5 & 0.5 & 4 & 0.5 \\
\hline Luxemburg & 15 & 0.1 & 1 & 0.1 \\
\hline Italy & 7 & 0.6 & 6 & 0.7 \\
\hline Denmark & 5 & 0.5 & 4.5 & 0.6 \\
\hline Other European countries & 4.5 & 0.4 & 13.5 & 1.7 \\
\hline Australia & 95 & 8.6 & 95 & 11.5 \\
\hline Canada & 45 & 4.1 & 40 & 4.3 \\
\hline USA & 35 & 3.2 & 35 & 4.3 \\
\hline Other non-European & 25 & 2.3 & 40 & 4.3 \\
\hline countries & 1000 & 100 & 825 & 100 \\
\hline TOTAL & & & & \\
\hline
\end{tabular}

In spite of its ideological skepticism regarding the migration of its citizens to the 'capitalist West' the Yugoslav regime not only tolerated but also supported the migration flows in the 1960s and 1970s. Obviously, the regime in Belgrade perceived the labor emigration as an efficient way to unload surplus workers. The Yugoslav sources suggest that the principal objective of the Yugoslav emigration policy was

$5 \quad$ Ibid.

6 Karolina Novinscak, „The Recruiting and Sending of Yugoslav ,Gastarbeiter to Germany: Between Social Demands and Economic Needs", in: Transnational Societies, Transteritorial Politics. Migrations in the (Post-) Yugoslav Regions 19 $9^{\text {th }}-21^{\text {th }}$ Century, ed. Ulf Brunnbauer, München, 2009, 128.

7 AJ, 142, f-740, Savezni komitet za rad i zapošljavanje, Izveštaj o ostvarivanju politike zapošljavanja zapošljavanja u inostranstvu, i postepenog vraćanja jugoslovenskih građana sa privremenog rada u inostranstvu u 1977. godini (analitičko-dokumentarna osnova), March 1978. 
to reduce the pressure on the Yugoslav labor market by allowing the emigration of unemployed and unskilled labor force. At the same time the Yugoslav regime sought to set the limits as to the emigration of skilled workers.

This selective emigration policy of the regime in Belgrade was reflected in the legal framework for the 'export' of surplus workers created by the federal government in the early 1960s. In March 1962 the Federal Executive Council underlined the necessity of exporting unemployed workers and preventing emigration of employed skilled workers. This goal of the Yugoslav regime was put into practice by the Federal Ministry of Labor, which adopted instructions for employment of the Yugoslav workers abroad. Being approved by the Federal government, the instructions came into force on $23^{\text {rd }}$ October 1963. The instructions of the Federal Ministry of Labor intended to foster the emigration of unskilled workers while imposing restrictions on emigration of skilled and highly skilled workers. The standard procedure provided that they could leave the country only with the permission of the Yugoslav Public Employment Services. The Federal Ministry of Labor entrusted the municipal authorities with deciding on the citizens' emigration applications, taking into account the Yugoslav economic interests. ${ }^{8}$ According to Yugoslav sources, the labor migration flows from Yugoslavia did not evolve into a brain drain. In the late 1970 s only $0.2 \%$ of the Yugoslav labor emigrants held uuniversity degrees. ${ }^{9}$

The emigration policy of the Yugoslav regime was summarized in the document of the Federal Labor Office, issued in 1970. The document underlined the necessity of accommodating the emigration strategy to the Yugoslav economic „interests and needs“. In this respect, the Yugoslav Labor Office gave priority to the 'export' of unemployed and unskilled labor force. ${ }^{10}$

Nevertheless, the procedure for the export of surplus workers from Yugoslavia did not takeroot, since the majority of the Yugoslav labor migrants emigrated bypassing the Yugoslav institutions. According to Yugoslav sources, in 1973 only 30,000 (out of 104,000 ) jobseekers left Yugoslavia with the permission of the Yugoslav Labor Offices. The others emigrated to the West using their individual contacts i.e. through support of the social (migrant) networks abroad. ${ }^{11}$

Despite anticipated positive implications of the migration flows from Yugoslavia for the Yugoslav economy (reducing unemployment, remittances of labor migrants), the communist regime in Yugoslavia had considerable reservations about the Gastarbeiter emigration in the 1960s and 1970s. According to Yugoslav sources, the regime in Belgrade was deeply concerned about the ideological, i.e. political consequences of this enterprise. The emigration from socialist Yugoslavia was anything but a simple migration from one country to another. Leaving their homeland and gaining a foothold in the western capitalist societies the jobseekers from Yugoslavia jumped over the Iron Curtain, which confronted them with the

8 Vladimir Ivanović, Geburtstag pišeš normalno. Jugoslovenski gastarbajteri u SR Nemačkoj i Austriji 1965-1973, Beograd, 2012, 57-58.

9 AJ, 142, f-740, Savezni komitet za rad i zapošljavanje, Izveštaj o ostvarivanju politike zapošljavanja, zapošljavanja u inostranstvu i postepenog vraćanja jugoslovenskih građana sa privremenog rada u inostranstvu u 1977. godini, March 1978.

10 AJ, 142, f-475, Savezni savet za rad, Neki elementi politike zapošljavanja u inostranstvu, November 1970 .

Ibid. 
new ideological values in the host countries. Therefore, the Yugoslav regime feared of potential „ideological indoctrination“ of the Yugoslav Gastarbeiter in the West. Since the government expected the repatriation of considerable number of Yugoslav „workers temporarily employed abroad" the regime could not be indifferent to their potential political and ideological re-shaping. In this regard the Yugoslav regime was fearful of their „westernization“, as a result of their integration into host societies, and the repercussions of their „westernization“ on the socialist system in Yugoslavia.

The contacts of the labor migrants with the political emigrants from former Yugoslavia were seen as another severe threat to the socialist system in Yugoslavia. The bulk of the Yugoslav political emigration consisted of the anticommunists (particularly Croats and Serbs) who had left the country after the Second World War. In 1952 the number of Yugoslav political emigrants was estimated at 94,000, about 64 per cent of whom lived in the United States, Canada and Europe. According to Yugoslav sources, Serbs represented the largest group of the political refugees from socialist Yugoslavia, accounted for nearly 50 per cent of Yugoslav political emigrants in $1952 .{ }^{12}$

Having escaped from Yugoslavia they continued their „war" against the communist regime in Belgrade sometimes using even the most radical methods. In 1970 the Yugoslav Foreign Ministry catalogued eleven right-wing organizations of the Serb diaspora in Western Europe, the United States, Canada and Australia, consisting, among others, of the Serbian anti-communist veterans of the Second World War (Srpska narodna odbrana, Srpski kulturni klub Sveti Sava, Udruženje boraca kraljevske jugoslovenske vojske Draža Mihailović, Pokret srpskih četnika - Ravna Gora, Zbor, Južnoslovenski demokratski savez, Savez oslobođenja, Srpski omladinski pokret Otadžbina, Srpski četnički centar, Udruženje Jugoslovena u Švedskoj, Srpski nacionalni odbor). ${ }^{13}$

In order to protect the ideological purity of its Gastarbeiter the Yugoslav regime endeavored to control not only the recruitment of the labor migrants but also their everyday life abroad. For that purpose the Belgrade regime founded an extensive network of Gastarbeiter associations in the most important receiving countries. In the late 1970s there were hundreds of such clubs for the Yugoslav workers in the Federal Republic of Germany, Austria, Switzerland, Sweden, Great Britain, France and Belgium. The Gastarbeiter clubs represented an important tool of the Yugoslav propaganda machinery targeting the Yugoslav labor migrants abroad. ${ }^{14}$

Besides, the Yugoslavs desperately tried to control the education of the second generation of the Yugoslav labor emigrants, aiming to prevent their ideological indoctrination in the capitalist West. For that reason the Yugoslav government launched educational programs for Yugoslav school children in their native language in the most important receiving countries with the aim to instill the key elements of the Yugoslav ideological Weltanschauung (Marxism-Leninism, Yugoslav patriotism, the cult of Tito) in the Gastarbeiter's offspring. ${ }^{15}$

12 Radmila Radić, Država i verske zajednice 1945-1970, Beograd, 2002, 292.

13 AJ, 142, f-474, Državni sekretarijat za inostrane poslove, Problemi vezani za aktivnost političke emigracije i potreba stalne i koordinirane protuakcije, June 1970.

14 Petar Dragišić, „Klubovi jugoslovenskih radnika u Zapadnoj Evropi sedamdesetih godina“, Tokovi istorije, 1/2010, 128-138.

15 AJ, 142, f-275, Odsek za školovanje jugoslovenske dece u inostranstvu, Informacija o nekim aktuelnim organizacionim pitanjima dopunske nastave za decu jugoslovenskih građana na 
The efforts to control the recruitment of the Yugoslav „workers temporarily employed abroad" as well as their political and ideological orientation reveal the ambivalent attitude of the Yugoslav regime towards the labor emigration from Yugoslavia. On one hand, it was perceived as an opportunity to relax the pressure on the Yugoslav labor market. On the other hand, the Yugoslav political elite was concerned about potential negative economic effects of the migration flows from Yugoslavia, such as emigration of skilled workers. The political consequences of the Gastarbeiter emigration were another major worry of the communist regime in Yugoslavia.

Being the biggest federal unit of former Yugoslavia Serbia contributed considerably to the migration flows from Yugoslavia since the 1960s. In 1981 more than one third of the Yugoslav Gastarbeiter population came from the Socialist Republic of Serbia and its autonomous provinces - Vojvodina and Kosovo. Nevertheless, the share of labor migrants in the total population was rather small in comparison with the top exporters of the labor force in former Yugoslavia. Whereas in 1971 only $2.4 \%$ of Serbian citizens worked abroad, the share of Gastarbeiter coming from Croatia and Bosnia and Herzegovina reached 5\% and $3.7 \%$ respectively. ${ }^{16}$

According to the 1971 census, there were 228,115 „workers temporarily employed abroad" and their family members coming from the Socialist Republic of Serbia. Ten years later the number of Serbian citizens living and working abroad increased by approximately 80,000. The official statistics from the 1991 census suggest a slight decline in the Serbian population abroad $(278,724)$. Nevertheless, given the decision of the vast majority of the ethnic Albanian in the Socialist Autonomy Province of Kosovo as well as in the southern districts of the Central Serbia (Bujanovac, Preševo) to boycott the census, the estimated number of the Serbian citizens abroad (labor migrants and their family members) was 60,000 higher compared to 1981. The majority of the 'workers temporarily employed abroad' came from Central Serbia (uža Srbija). In 1981 the share of the migrant workers and their family members coming from Central Serbia in the total Gastarbeiter population from Serbia accounted for 65\%. The 1981 census suggests

privremenom radu u inostranstvu, 8. 6. 1976; AJ, 142, f-275, Savezni zavod za međunarodnu naučnu, prosvetno-kulturnu i tehničku saradnju, Savetovanje o dopunskoj nastavi (Novi Sad 29-30. 6. 1976); AJ, 142, f-474, Savezni zavod za obrazovanje i kulturu, Društveno-pedagoška osnova obrazovno-vaspitnog rada sa decom naših radnika privremeno zaposlenih u inostranstvu i predlozi za rešavanje problema njihovog školovanja, 5. 5. 1970; AJ, 142, f-275, Savezni zavod za međunarodnu naučnu, prosvetno-kulturnu i tehničku saradnju, Izveštaj Rodoljuba Ignjatovića o obilasku dopunske i prelazne nastave u SR Nemačkoj i o održanim predavanjima od 2. do 6. 6. 1976; AJ, 142, f-275, Informacija ambasade SFRJ u Bernu o jugoslovenskim dopunskim školama na području Švajcarske, april 1976; AJ, 142, f-277, Savezni sekretarijat za inostrane poslove (Uprava za radnike u inostranstvu), Jugoslovenski građani na privremenom radu u Švajcarskoj - Problematika zapošljavanja, rada i boravka, jun 1978; AJ, 142, f-276, Generalni konzulat SFRJ Frankfurt, Dopunsko školovanje (1976).

16 Ulf Brunnbauer, „Jugoslawische Geschichte als Migrationsgeschichte (19. und 20. Jahrhundert)“, in Schnittstellen. Gesellschaft, Nation, Konflikt und Erinnerung. Festschrift für Holm Sundhaussen zum 65. Geburtstag, ed. Ulf Brunnbauer et al., München, 2007, 119. 
that the second largest exporter of the Serbian labor force was the Socialist Autonomy Province of Vojvodina (21\%). Nevertheless, ten years later (1991) the estimated number of the migrants from the Socialist Autonomy Province of Kosovo was slightly bigger than those from Vojvodina. ${ }^{17}$

Workers temporarily employed abroad and their family members - from the Socialist Republic of Serbia ${ }^{18}$

\begin{tabular}{|c|r|r|r|}
\hline & Workers & Family members & \multicolumn{1}{c|}{ Total } \\
\hline 1971 & 198,220 & 29,895 & 228,115 \\
\hline 1981 & 229,975 & 78,451 & 308,446 \\
\hline 1991 & 202,850 & 75,874 & 278,724 \\
\hline 1991 estimation & & & 337,686 \\
\hline
\end{tabular}

Workers temporarily employed abroad and their family members from Central Serbia (uža Srbija) ${ }^{19}$

\begin{tabular}{|c|r|r|r|r|}
\hline & Workers & Family members & Total & \multicolumn{1}{c|}{ Share of population } \\
\hline 1971 & 114,581 & 18,808 & 133,389 & 2.5 \\
\hline 1981 & 152,932 & 50,489 & 203,421 & 3.6 \\
\hline 1991 & 162,692 & 58,729 & 221,421 & 3.9 \\
\hline 1991 estimation & & & 226,295 & 3.9 \\
\hline
\end{tabular}

Workers temporarily employed abroad and their family members - from Vojvodina ${ }^{20}$

\begin{tabular}{|r|r|r|r|r|}
\hline & Workers & Family members & Total & \multicolumn{1}{c|}{ Share of population } \\
\hline 1971 & 60,644 & 9,948 & 70,592 & 3.6 \\
\hline 1981 & 48,078 & 17,513 & 65,591 & 3.2 \\
\hline 1991 & 33,975 & 13,565 & 47,522 & 2.4 \\
\hline
\end{tabular}

Workers temporarily employed abroad and their family members - from Kosovo ${ }^{21}$

\begin{tabular}{|c|r|r|r|r|}
\hline & \multicolumn{1}{|c|}{ Workers } & Family members & \multicolumn{1}{c|}{ Total } & \multicolumn{1}{c|}{ Share of population } \\
\hline 1971 & 22,995 & 1,139 & 24,134 & 1.9 \\
\hline 1981 & 28,695 & 10,469 & 39,434 & 2.5 \\
\hline 1991 & 6,201 & 3,508 & 9,781 & 2.7 \\
\hline 1991 estimation & & & 63,869 & 3.3 \\
\hline
\end{tabular}

17 Republika Srbija, Republički zavod za statistiku, Stanovništvo i domaćinstva Republike Srbije prema popisu 1991. godine

18 Ibid.

19 Ibid.

20 Ibid.

21 Ibid. 
The last census conducted in Serbia in the socialist period (1991) suggests that Germany and Austria received almost 50\% of the Gastarbeiter population from Serbia. According to the statistics from the 1991 census, the community of Serbian citizens in Germany accounted for $25 \%$ of the Gastarbeiter from the Socialist Republic of Serbia. In addition, a considerable number of the guest workers from Serbia lived in Switzerland, France and Sweden. Typical of the Gastarbeiter emigration from Serbia was, in comparison to the Yugoslav average, a large percentage of Serbian immigrants in Austria. Whereas in 1977 the Yugoslav community in Austria accounted for $14.7 \%$ of the Yugoslav Gastarbeiter, the 1991 census recorded that roughly $24 \%$ of the labor migrants and their family members from Serbia were domiciled in the Austria. Nevertheless, Austria was far from being a favored destination for labor migrants from the Socialist Autonomy Province of Kosovo. The 1991 census recorded only $4.6 \%$ of the immigrants from Kosovo living in Austria. ${ }^{22}$

The statistics on the labor migration from Serbia from the beginning of the 1960s to the dissolution of the Socialist Federal Republic of Yugoslavia suggest that the bulk of the workers temporarily employed abroad and their families resided in Western Europe. The 1991 census recorded a relatively small number of guest workers from Serbia in the non-European countries.

Citizens of the Socialist Republic of Serbia temporarily residing abroad 1991 (by receiving countries) ${ }^{23}$

\begin{tabular}{|c|r|r|r|r|r|r|r|r|}
\hline & \multicolumn{2}{|c|}{ Serbia } & Central Serbia & \multicolumn{2}{c|}{ Vojvodina } & \multicolumn{2}{c|}{ Kosovo } \\
\hline Austria & 67,551 & $24.2 \%$ & 58,623 & $26.5 \%$ & 8,437 & $17.8 \%$ & 451 & $4.6 \%$ \\
\hline Belgium & 757 & $0.3 \%$ & 681 & $0.3 \%$ & 56 & $0.1 \%$ & 20 & $0.2 \%$ \\
\hline Denmark & 2,207 & $0.8 \%$ & 1,770 & $0.8 \%$ & 417 & $0.9 \%$ & 20 & $0.2 \%$ \\
\hline France & 22,641 & $8.1 \%$ & 21,097 & $9.5 \%$ & 1,260 & $2.7 \%$ & 284 & $2.9 \%$ \\
\hline Netherlands & 2,399 & $0.9 \%$ & 1,962 & $0.9 \%$ & 381 & $0.8 \%$ & 56 & $0.6 \%$ \\
\hline Italy & 5,515 & $2 \%$ & 5,022 & $2.3 \%$ & 387 & $0.8 \%$ & 106 & $1.1 \%$ \\
\hline Luxembourg & 528 & $0.2 \%$ & 458 & $0.2 \%$ & 53 & $0.1 \%$ & 17 & $0.2 \%$ \\
\hline Germany & 70,839 & $25.4 \%$ & 46,291 & $20.9 \%$ & 20,938 & $44.1 \%$ & 3,610 & $36.9 \%$ \\
\hline Switzerland & 41,046 & $14.7 \%$ & 33,559 & $15.2 \%$ & 3,882 & $8.2 \%$ & 3,605 & $36.9 \%$ \\
\hline Sweden & 10,039 & $3.6 \%$ & 7,796 & $3.5 \%$ & 2,133 & $4.5 \%$ & 110 & $1.1 \%$ \\
\hline UK & 1,740 & $0.6 \%$ & 1,507 & $0.7 \%$ & 204 & $0.4 \%$ & 29 & $0.3 \%$ \\
\hline Other European countries & 2,343 & $0.8 \%$ & 1,691 & $0.8 \%$ & 510 & $1.1 \%$ & 142 & $1.5 \%$ \\
\hline North and Middle America & 13,988 & $5 \%$ & 10,528 & $4.7 \%$ & 3,165 & $6.7 \%$ & 295 & $3 \%$ \\
\hline South America & 334 & $0.1 \%$ & 301 & $0.1 \%$ & 26 & $0.1 \%$ & 7 & $0.1 \%$ \\
\hline Africa & 1,448 & $0.5 \%$ & 1,284 & $0.6 \%$ & 135 & $0.3 \%$ & 29 & $0.3 \%$ \\
\hline Australia & 5,098 & $1.8 \%$ & 3,748 & $1.7 \%$ & 1,317 & $2.8 \%$ & 33 & $0.3 \%$ \\
\hline Oceania & 76 & $0.0 \%$ & 57 & $0.0 \%$ & 17 & $0.0 \%$ & 2 & $0.0 \%$ \\
\hline Asia & 1,145 & $0.4 \%$ & 1,022 & $0.5 \%$ & 104 & $0.2 \%$ & 19 & $0.2 \%$ \\
\hline Other countries & 29,070 & $10.4 \%$ & 24,024 & $10.8 \%$ & 4,100 & $8.6 \%$ & 946 & $9.7 \%$ \\
\hline Total & 278,724 & $100 \%$ & 221,421 & $100 \%$ & 47,552 & $100 \%$ & 9,781 & $100 \%$ \\
\hline
\end{tabular}


Serbian statistics reveal the existence of the Gastarbeiter stronghold in northeastern Serbia. According to the 1981 census, in the municipalities of Žabari, Malo Crniće and Svilajnac the Gastarbeiter and their family members made up more than $20 \%$ of the local population. In contrast to the large percentage of labor migrants from this part of Central Serbia the economic migration from the central parts of Vojvodina, the western parts of Central Serbia as well as from southeastern Serbia was far less extensive. ${ }^{24}$

The statistical data on the educational level of the Serbian Gastarbeiter show a clear majority of the unskilled workers among the labor migrants from Serbia. According to the 1981 census, the labor migrants with secondary and tertiary education made up only $22.3 \%$ of the Gastabeiter population from Serbia. The percentage of migrants with secondary and tertiary education was particularly low in Kosovo $-11.4 \% .{ }^{25}$ In spite of the inability of the Yugoslav regime to tightly control the economic migration from Yugoslavia, the official statistics suggest that the „exodus" from Serbia from the early 1960s to the dissolution of the Socialist Federal Republic of Yugoslavia corresponded to the main goal of the Yugoslav emigration strategy - stimulation of the export of the unqualified jobseekers, while keeping qualified and highly educated workers in Yugoslavia. In contrast to the extensive migration from Serbia during the 1990s the labor migration from Serbia during the socialist era did not escalate into brain drain.

The educational background of the labor migrants from Serbia played an important role in creating the image of Serbian Gastarbeiter in their homeland. The predominance of low-educated migrants in the Gastarbeiter population from Serbia shaped significantly the public perceptions of the „workers temporarily employed abroad“. In the 1970s and 1980s the negative stereotypes of the Gastarbeiter were commonplace in the Serbian film industry. The Gastarbeiter were depicted in the Serbian movies, as a rule, as impolite and uneducated nouveaux riches. Another locus communis was Gastarbeiter's above average wealth. ${ }^{26}$ Nevertheless, this stereotype was not completely unfounded. According to Yugoslav estimates from 1970, the Yugoslav Gastarbeiter used to earn approximately 2.5-3 times the wages of their colleagues in Yugoslavia. ${ }^{27}$

The migration flows Serbia from the 1960s to the beginning of the 1990s have had a significant impact on the Serbian economy. The export of labor force certainly contributed to some extent to reducing the pressure on the Serbian

24 Republički zavod za statistiku SR Srbije i Centar za demografska istraživanja IDN, Stanovništvo $i$ domaćinstva SR Srbije prema popisu 1981. Ibid.

26 Sara Bernard, „Il ritorno dei gastarbajteri nella politica migratoria della Jugoslavia socialista (1969-1991)“, Percorsi storici, 1/2013, [http://www.percorsistorici.it/numeri/numero-1/titolo-eindice/saggi/sara-bernard-il-ritorno-dei-gastarbajteri-nella-politica-migratoria-della-jugoslaviasocialista-1969-1991]; Vladimir Ivanović, Geburtstag pišeš normalno, 309-313; Predrag Marković, „Gastarbeiters as the factor of Modernization of Serbia“, Istorija 20. veka, 2/2005, 150.

27 AJ, 142, f-475, Radna grupa Savjeta Izvršnog vijeća Sabora za odnose s inozemstvom, Zapošljavanje naših građana u inozemstvu, Zagreb, May 1970. 
labor market during the socialist era. Besides, the Gastarbeiter migration has had profound financial effects, given that the remittances of the Yugoslav „workers temporarily employed abroad" have been a significant source of foreign currency. This effect of the labor migration from Yugoslavia became noticeable already in the early phase of the export of Yugoslav labor force. In 1972 the remittances of the Yugoslav labor migrants for the first time exceeded one billion dollars. A decade later, the sum of the remittances was four times greater. ${ }^{28}$

The remittances of the emigrants have continued to play an important role in the economies of the Yugoslav successor states after the dissolution of the Socialist Federal Republic of Yugoslavia. The economic collapse during Milošević's era made Serbia extremely dependent on the cash infusions from the Serbian diaspora. For many citizens of Serbia the financial support of their relatives from the West was the only source of income during the „years of lead" in Serbia in the 1990s. Nevertheless, the impact of the Gastarbeiter and other segments of the Serbian emigration on Serbia in this epoch had also political aspects.

The rise of nationalism in former Yugoslavia in the late 1980s and the Yugoslav disintegration at the beginning of the 1990s eliminated the border between political and labor migrants from Serbia. The nationalistic sentiments in the homeland had a significant impact on the Weltanschauung of many labor migrants from Serbia, resulting in their politicization and radicalization. Their longdistance nationalism manifested itself particularly in financial and humanitarian support for their compatriots in the home country. In 1989 the Serbian diaspora contributed enormously to Milošević's fundraising project - „loan for the economic reconstruction of Serbia" (Zajam za privredni preporod Srbije). Besides, in the course of the Yugoslav wars in the 1990s the Serbian emigration supported their native land through charitable activities. During the wars of Yugoslav succession many Serbian migrants in the West also participated politically in the Yugoslav crisis. Lobbying and protest rallies, particularly during the NATO campaign against the Federal Republic of Yugoslavia in 1999, were paradigmatic expression of the long-distance nationalism of the diaspora-Serbs. ${ }^{29}$

Given the modest economic growth of post-Milošević's Serbia, the Serbian economy remains heavily reliant on the cash infusions of the Serbian emigrants. The recent World Bank statistics record a permanent growth of remittances to Serbia. Whereas in 2006 (the year of the dissolution of the State Union of Serbia and Montenegro) the remittances to Serbia amounted to 4.7 billion dollars, three years later the Serbian migrants transferred to Serbia round 5.4 billion dollars. The World Bank statistics suggest a major impact of the Gastarbeiter's financial resources on the Serbian economy. In 2009 the share of the remittances of the Serbian GDP was estimated at $13 \% .^{30}$

28 Waltraut Urban, „Die Wirtschaftsbeziehungen zwischen Österreich und Jugoslawien 1955-1985“, in Österreich und Jugoslawien: Determinanten und Perspektiven ihrer Beziehungen, ed. Otmar Höll, Wien, 1988, 385.

29 Birgit Bock-Luna, The Past in Exile. Serbian Long-Distance Nationalism and Identity in the Wake of the Third Balkan War, Berlin, 2008, 44, 109-113, 120; Paul Hockenos, Homeland Calling. Exile Patriotism and the Balkan Wars (Cornell University Press, Ithaca-New York, 2003), 106, 126, 164-165; Harald Waldrauch, Karin Sohler, Migrantenorganisationen in der Großstadt: Entstehung, Strukturen und Aktivitäten am Beispiel Wien, Wien, 2004, 208-215; Sam Pryke, „British Serbs and long-distance nationalism", Ethnic and Racial Studies 1 (2003), 154-155.

The World Bank, Migration and Remittances Fact book 2011. 
Top remittance-receiving countries in 2010 (in \$ billions) ${ }^{31}$

\begin{tabular}{|l|r|l|r|}
\hline India & 55.0 & Pakistan & 9.4 \\
\hline China & 51.0 & Poland & 9.1 \\
\hline Mexico & 22.6 & Lebanon & 8.2 \\
\hline Philippines & 21.3 & Egypt & 7.7 \\
\hline France & 15.9 & UK & 7.4 \\
\hline Germany & 11.6 & Vietnam & 7.2 \\
\hline Bangladesh & 11.1 & Indonesia & 7.1 \\
\hline Belgium & 10.4 & Morocco & 6.4 \\
\hline Spain & 10.2 & Russian Federation & 5.6 \\
\hline Nigeria & 10.0 & Serbia & $\mathbf{5 . 6}$ \\
\hline
\end{tabular}

Notwithstanding the „generosity“ of the Serbian Gastabeiter, their savings have not significantly contributed to the economic modernization of Serbia. The attempts of the Yugoslav communist regime to attract investments of its emigrants through „Gastarbeiter factories“ had little success. ${ }^{32}$ Likewise, the post-communist governments of Serbia have failed to motivate the diaspora-Serbs to invest their savings in the Serbian economy. As a consequence, a lion's share of the considerable financial resources of the Serbian emigration has gone into private consumption. ${ }^{33}$ The most eye-catching unproductive investments of the diaspora-Serbs are their lavish houses in their native land. The grandiose houses, which exceed the needs of the emigrants and their families, became unique status symbols of the Serbian Gastarbeiter. $^{34}$

Nevertheless, the influence of the Serbian Gastabeiter emigration on their native land is not only limited to the strong financial support. The Gastabeiter and their descendants are well integrated into the receiving societies while maintaining close ties with their country of origin. Thus, through levitation between "here and there" the large Serbian Gastarbeiter communities, together with the other segments of the Serbian diaspora, became an alternative „channel“ between Serbia and the Gastabeiter's host countries in the West. In this regard, the German historian, Ulf Brunnbauer, underlined the role of the Yugoslav Gastabeiter in transferring „new cultural patterns and values“ from the receiving countries to their homeland. ${ }^{35}$

31 Ibid.

32 Ulf Brunnbauer, „Labor Emigration from the Yugoslav Region from the late $19^{\text {th }}$ Century until the End of Socialism: Continuities and Changes", in Transnational Societies, Transteritorial Politics. Migrations in the (Post-) Yugoslav Regions $19^{\text {th }}-21^{\text {th }}$ Century, ed. Ulf Brunnbauer, München, 2009, 46.

33 http://www.politika.rs/rubrike/vesti-dana/Srbiji-od-dijaspore-55-milijardi-dolara.lt.html (accessed April 2014); Ulf Brunnbauer, „Labor Emigration“, 46.

34 Predrag Marković, „Gastarbeiters“, 155; Ulf Brunnbauer, „Labour Emigration“, 34.

35 Ulf Brunnbauer, „Labour Emigration“, 49. 


\section{Резиме}

Др Петар Драгишић

\section{У потрази за Елдорадом. Радници из Србије на привременом раду у иностранству од 60-их година до распада Југославије}

Кључне речи: економска емиграција, гастарбајтери, Србија, Југославија, дознаке

Шездесетих година прошлог века социјалистичка Југославија је била суочена са политичким тензијама и економском стагнацијом. Криза на тржишту рада приморала је стотине хиљада Југословена да посао потраже изван граница земље. Највећи талас емиграције из Југославије трајао је до почетка 70-их година, када је у иностранству радило више од милион југословенских гастарбајтера. За Југословене на привременом раду y иностранству кључне дестинације биле су земље немачког говорног простора.

Према србијанским статистичким подацима, 1971. у иностранству је живело близу 230.000 гастарбајтера из Србије и чланова њихових породица. У наредним деценијама тај број се увећао, па је у години распада Социјалистичке Федеративне Републике Југославије (1991) у иностранству живело, према резултатима пописа, око 280.000 миграната из Србије. Процењено је, међутим, да је реалан број био за око 60.000 већи. Најзначајнији удео у укупном броју миграната из Социјалистичке Републике Србији имали су мигранти из централне Србије. Извоз радне снаге посебно је био карактеристичан за подручје североисточне Србије. Према резултатима пописа из 1981, у општинама Жабари, Мало Црниће и Свилајнац удео емиграната у локалној популацији прелазио је 20\%. Статистички извори указују на значајно низак образовни ниво миграната из Социјалистичке Републике Србије.

На Србију, као и на остале југословенске републике, интензивна гастарбајтерска емиграција имала је двоструки економски ефекат. С једне стране, одлив вишкова радне снаге растеретио је домаће тржиште рада. Са друге стране, гастарбајтерске дознаке представљале су и представљају значајну економску инјекцију за Србију и остале земље региона. 